\title{
The mycorrhization involvement in the productivity of three potato varieties in terms of an artificial in- fection with Fusarium sambucinum Fuckel
}

\author{
Ioana Daniela BORCA, Carmen Emilia PUIA*
}

Faculty of Agriculture, Department of Environmental and Plant Protection, University of Agricultural Sciences and Veterinary Medicine, Manastur Street, No. 3-5, 400372, Cluj-Napoca, Romania

* corresponding author: carmen.puia@yahoo.com

Bulletin USAMV series Agriculture 71(2)/2014

Print ISSN 1843-5246; Electronic ISSN 1843-5386

DOI 10.15835/buasvmcn-agr: 10599

\begin{abstract}
The achieved production of three varieties of potato, quantified by the tubers weight, in terms of an artificial infection with Fusarium sambucinum Fuckel were analysed in order to see the influence of the additional inoculation with mycorrhizal fungi.

The artificial infection had a negative impact on the production for all three varieties of potato. In this terms, the production parameter followed varied between $823.04 \mathrm{~kg} / \mathrm{ha}$ for the semi-early variety, $864.19 \mathrm{~kg} / \mathrm{ha}$ for the late variety and $1028.8 \mathrm{~kg} / \mathrm{ha}$ for the early variety.

The additional mycorrhization has mitigated the effect of the artificial infection with Fusarium sambucinum Fuckel for all three varieties of potato taken into account. In this conditions, the tubers weight varied between $1028.8 \mathrm{~kg} / \mathrm{ha}$ for the late variety of potato, $1193.41 \mathrm{~kg} / \mathrm{ha}$ for the early variety of potato and $1522.63 \mathrm{~kg} / \mathrm{ha}$ for the semi-early variety of potato.
\end{abstract}

Keywords: artificial infection, colonization, mycorrhiza, potato

Introduction. Fusarium dry rot of seed tubers produced by Fusarium sambucinum Fuckel can reduce crop establishment by killing developing potato sprouts and crop losses can be up to $25 \%$, while more than $60 \%$ of tubers can be infected in storage (Wharton and Kirk, 2014). Stimulation of host-plant resistance mechanisms, importance of plant nutrition, direct interaction between vesicular arbuscular mycorrhizal fungi (VAMF) mycelium and pathogens, or indirect effects through changes in soil microflora have been studied by Filion at al. (1999) and proposed to explain the influence of arbuscular mycorrhizal fungi on disease development.

Aims and objectives. The aim of this study was to determine the effect of an additional mycorrhizal inoculation in the productivity of three potato varieties artificially infected with
Fusarium sambucinum Fuckel by measured the weight $(\mathrm{kg} / \mathrm{ha})$ of the tubers.

Materials and methods. The experimental plot was located at $46^{\circ} 54^{\prime} 20^{\prime \prime} \mathrm{N}$ latitude, $23^{\circ} 46^{\prime} 06^{\prime \prime}$ E longitude and at an altitude of 285 $\mathrm{m}$ in Rascruci, Cluj County, Romania. For the research experiment it was used the method of subdivided plots with three varieties of potatoes that differs in vegetation period: early variety (Roclas), semi-early variety (Christian) and late variety (Gared). For the mycorrhizal inoculum it was used a mixture of arbuscular mycorrhizal fungi (200.000 propagules per liter material of AM fungi, concentrated at an inorganic carrier) like: Glomus mosseae, Glomus intraradices, Glomus clarum, Glomus monosporus, Glomus deserticola, Glomus brasilianum, Glomus aggregatum, Glomus etunicatum, Glomus fasciculatum, Gigaspora margarita. The pathogen inoculum was produced 
Tab. 1. The influence of additional mycorrhization on the tubers weight of potato under artificial infection with Fusarium sambucinum Fuckel

\begin{tabular}{|c|c|c|c|c|c|c|c|}
\hline Variety & $\begin{array}{l}\text { Fusarium spp. } \\
\text { infection type }\end{array}$ & $\begin{array}{c}\text { Mycorrhization } \\
\text { type }\end{array}$ & $\begin{array}{l}\text { Tubers } \\
\text { weight }\end{array}$ & $\begin{array}{c}\% \text { to } \\
\text { control }\end{array}$ & $\begin{array}{l}\text { Difference } \\
\text { to control }\end{array}$ & $\begin{array}{c}\text { Difference } \\
\text { significance }\end{array}$ & $\begin{array}{c}\text { Duncan } \\
\text { test }\end{array}$ \\
\hline $\begin{array}{l}\text { Varieties } \\
\text { average }\end{array}$ & natural & natural & 1152.26 & 100 & 0 & Mt & - \\
\hline \multirow{4}{*}{ Early } & \multirow{2}{*}{ natural } & natural & 1481.48 & 128.6 & 329.22 & - & $\mathrm{AB}$ \\
\hline & & additional & 1563.78 & 135.7 & 411.52 & $*$ & $\mathrm{CD}$ \\
\hline & \multirow{2}{*}{ artificial } & natural & 1028.8 & 89.3 & -123.45 & - & $\mathrm{A}$ \\
\hline & & additional & 1193.41 & 103.6 & 41.16 & - & $\mathrm{AB}$ \\
\hline \multirow{4}{*}{$\begin{array}{l}\text { Semi- } \\
\text { early }\end{array}$} & \multirow{2}{*}{ natural } & natural & 946.5 & 82.1 & -205.76 & - & A \\
\hline & & additional & 1728.39 & 150 & 576.14 & $* *$ & $\mathrm{D}$ \\
\hline & \multirow{2}{*}{ artificial } & natural & 823.04 & 71.4 & -329.22 & - & $\mathrm{A}$ \\
\hline & & additional & 1522.63 & 132.1 & 370.37 & - & $\mathrm{ABCD}$ \\
\hline \multirow{5}{*}{ Late } & \multirow{2}{*}{ natural } & natural & 1028.8 & 89.3 & -123.45 & - & A \\
\hline & & additional & 1234.56 & 107.1 & 82.31 & - & BCD \\
\hline & \multirow{2}{*}{ artificial } & natural & 864.19 & 75 & -288.06 & - & A \\
\hline & & additional & 1028.8 & 89.3 & -123.45 & - & $\mathrm{ABC}$ \\
\hline & DL (p & 373.93 & $1 \%) 551.2$ & $\mathrm{DL}$ & p 0.1\%) 84C & 57 & \\
\hline
\end{tabular}

on PDA plates. For the infection of the potatoes it was used a Fusarium sambucinum Fuckel spores suspension, obtained from subcultured plates. Each potato plant infected artificially was inoculated with $10 \mathrm{ml}$ of Fusarium sambucinum Fuckel spore suspension $\left(10^{7}\right.$ spores $\left./ \mathrm{ml}\right)$ after 50 days from planting.

Results and Discussion. Regarding the productivity of the potatoes ( Tab. 1) expressed in the weight $(\mathrm{kg} / \mathrm{ha})$ of tubers, the negative effect of the artificial infection with Fusarium sambucinum Fuckel was reported in all potato varieties. This negative effect was diminished by the additional mycorrhizal colonization. The semi-early variety of potato was the most influenced from this point of view. This variety showed very significant negative differences under natural conditions of mycorrhizal colonization and under additional mycorrhization conditions it showed significant negative difference

In terms of favourability also the semi-early variety of potato had the lowest favourability under artificial infection by Fusarium sambucinum Fuckel and natural condition of mycorrhization, but the highest favourability under natural condition of infection by Fusarium sp. and additional colonization with mycorrhizal fungi.
Conclusion. The achieved production, quantified by the weight of the tubers, was positively influenced under additional mycorrhization condition, both in natural and artificial conditions of infection with Fusarium sp. The strongest effect from this point of view has been observed for the semi-early variety. The artificial infection with Fusarium sambucinum Fuckel had a negative impact on the production parameters for all the varieties of the experiment; the most affected being the semi-early variety.

\section{REFERENCES}

1. Filion M., St-Arnoud M. And Fortin J. A. (1999). Direct interaction between the arbuscular mycorrhizal fungus (Glomus intraradices) and different rhizosphere microorganisms. New Phytol. 141: 525-533.

2. Wharton P. S., Kirk W. W. (2014). Evaluation of biological seed treatments in combination with management practices for the control of Fusarium dry rot of potato. Biological Control. 73:23-30. 